\title{
¿Cuál sería su diagnóstico y su manejo terapéutico?
}

\section{What should the diagnosis and treatment be?}

Paciente mujer de 68 años de edad, que presenta masa ovárica sugestiva de cáncer de ovario y precisa intervención quirúrgica urgente por parte del servicio de ginecología de nuestro hospital. Se nos plantea una interconsulta, debido a que la paciente presenta una gran masa intraoral que imposibilita la intubación.

A la exploración, la paciente presenta una masa que ocupa toda la bóveda palatina, pediculada a encía de cresta alveolar de las piezas 15 a 17, de $5 \times 5 \mathrm{~cm}$, coloración rosácea similar al resto de al mucosa, superficie lisa, consistencia fibroelástica e íntimamente imbricada con una prótesis parcial removible (Figs. 1 y 2). La paciente refiere una evolución de 10 años durante los cuales la retirada y limpieza de la prótesis le resultó imposible. No refiere otra sintomatología relacionada.

Debido a la premura de la situación y con el diagnóstico de presunción de neoplasia benigna de maxilar vs hiperplasia mucosa se decide intervención quirúrgica urgente.

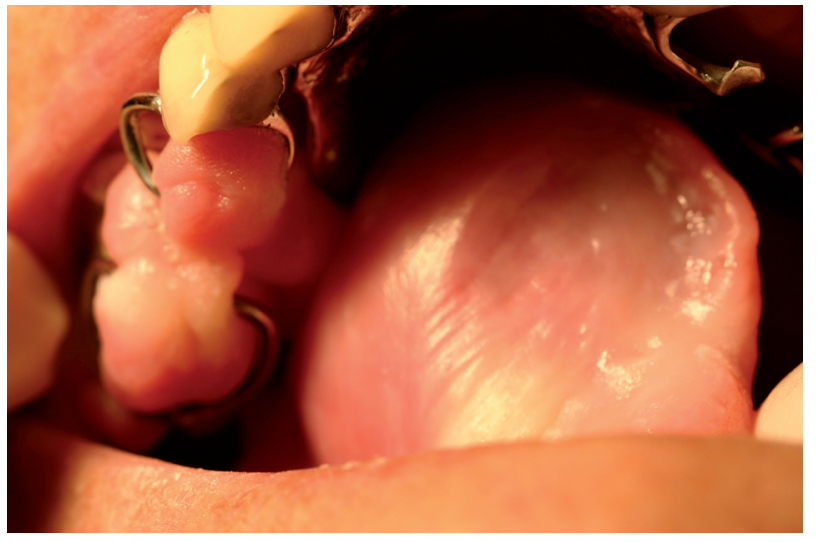

Figura 1. Figure 1.

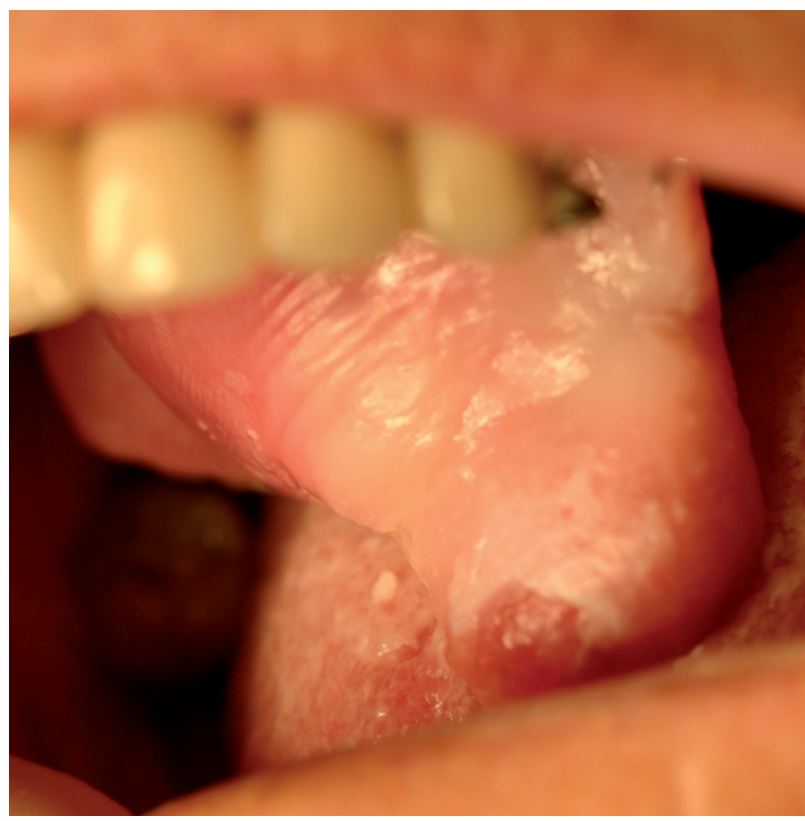

Figura 2. Figure 2.
Female patient, 68 years old, presented with an ovarian mass suggestive of ovarian cancer. She needed to be operated urgently by the gynecological service in our hospital. The issue of an interconsultation was raised, as the patient had a large intraoral mass that made intubation impossible.

On examination, a mass was observed that occupied the entire palatal vault. It was pedicled to the gingiva of the alveolar crest by teeth 15 to 17. It measured $5 \times 5 \mathrm{~cm}$, it was pinkish and similar to the rest of the mucosa. It had a smooth surface, a fibroelastic consistency and it was closely interwoven with a removable partial prosthesis. The patient reported that it had been evolving for 10 years during which time it had been impossible to remove and clean the prosthesis. There were no other related symptoms.

Given the pressurized circumstances, and with the presumed diagnosis of benign neoplasm of the maxilla vs. mucosal hyperplasia, a decision was made to operate urgently. 


\section{Fibroma osificante periférico}

\section{Peripheral ossifying fibroma}

\section{E. Charro Huerga' , I. Vázquez Mahía², G. Gómez Oliveira' ${ }^{1}$ S. Sironvalle Soliva ${ }^{1}$, J.L. López Cedrún ${ }^{3}$}

La paciente fue sometida a intervención quirúrgica bajo anestesia local para la exéresis de la lesión basándonos en los datos clínicos y en la exploración. Se realizó exéresis de la lesión con electrobisturí, retirada de la prótesis, exodoncia de los restos radiculares relacionados, legrado del lecho óseo y sutura parcial con material reabsorbible (Fig.3).

El estudio histológico de la pieza demostró la presencia de microcalcificaciones, con áreas de aspecto mixoide (Figs.4). El análisis microscópico reveló la existencia de un revestimiento mucoso de epitelio plano, poliestratificado, no queratinizado, con signos de hiperplasia reactiva, con papilomatosis y acantosis. El estroma estaba constituido por tejido fibroelástico, escasamente celular y no se evidenciaban mitosis. De forma dispersa se observaban calcificaciones correspondientes a trabéculas óseas mal configuradas. La histología correspondió a un fibroma osificante periférico.

La evolución de la paciente fue satisfactoria y tras 8 meses de seguimiento la paciente se encuentra asintomática, sin evidencia de signos de recidiva de la lesión.

\section{Discusión}

En el presente caso, debido la presentación clínica como una masa pediculada en encía, asintomática y de larga evolución, las opciones diagnósticas orientaban fundamentalmente a las hiperplasias y neoplasias benignas de la mucosa oral. Para este tipo de lesiones autores como Reqezzi y cols. ${ }^{1}$ diferencian dos subgrupos, epiteliales y conjuntivales. En las hiperplasias incluyen el fibroma irritativo (trauma de repetición), épulis fisurado (prótesis mal ajus-

\footnotetext{
1 Médico Residente.

2 Médico Adjunto.

3 Jefe de Servicio.

Servicio de Cirugía Oral y Maxilofacial

Hospital Juan Canalejo. A Coruña, España

Correspondencia:

Esther Charro Huerga

Hospital Teresa Herrera

Complexo Hospitalario Juan Canalejo

As Xubias De Arriba 84

15006 A Coruña, España

E-mail: esch26@hotmail.com
}

The patient underwent surgical excision of the lesion under local anesthesia based on clinical data and the examination. The excision of the lesion was carried out using an electric bistoury. The prosthesis was removed, exodontia of the relevant root remains was carried out together with curettage of the bony bed. The area was partially sutured with resorbable material.

The histological study of the specimen revealed the presence of microcalcifications and areas with a myxoid appearance. The microscopic analysis showed the existence of a mucosal lining with a flat, multilayered, non-keratinized epithelium. There were signs of reactive hyperplasia with papillomatosis and acanthosis. The stoma was made up of fibroelastic tissue, with sparse cellularity and there was no evidence of mitosis. Scattered calcifications corresponding to poorly defined bony trabeculae were observed. The histological features corresponded to a peripheral ossifying fibroma.

The patient evolved satisfactorily and, after a followup of eight months, she was asymptomatic and there were no signs of the lesion recurring.

\section{Discussion}

In this case, due to the clinical presentation of a pedicled mass in the gingiva that was asymptomatic and which had been developing for a long time, the diagnostic options pointed basically to benign hyperplasia or neoplasms of the oral mucosa. For this type of lesions, authors such as Regezzi $y$ cols. ${ }^{1}$ differentiate two subgroups, epithelial and conjuntival. Hyperplasias include irritation fibroma (repetitive trauma) epulis fisuratum, (badly adjusted prosthesis), pyogenic granuloma in pregnancy, peripheral ossifying fibroma and peripheral granuloma of giant cells. On the other hand the fibroma, lipoma, hemangioma, lymphangioma, schwannoma, neurofibroma, rhabdomyoma and leiomyoma fall into neoplasms. ${ }^{1}$

Benign fibro-osseous lesions of the maxilla have presented numerous problems with regard to diagnosis and 
tadas), granuloma biogénico gravídico, fibroma osificante periférico y granuloma periférico de células gigantes. Por otra parte, agrupan dentro de las neoplasias el fibroma, lipoma, hemangioma, linfangioma, schwanoma, neurofibroma, rabdomioma y leiomioma. ${ }^{1}$

Las lesiones benignas fibro-óseas de los maxilares han presentado numerosos problemas en su diagnóstico y clasificación. ${ }^{2}$ En el pasado, se han empleado diferentes términos para denominar a esta lesión: osteofibroma, fibroosteoma, fibroma cementificante, lesión benigna fibroósea del ligamento periodontal etc., creando gran confusión en cuanto a la terminología. Esto se debe, por un lado, a que clínica y radiológicamente pueden ser imposibles de diferenciar, y en segundo lugar, a la dificultad para distinguir el origen (en tejido óseo o en cemento) del material calcificado, siendo éste, un punto de gran controversia. 6 Por lo tanto, se consideraba el fibroma osificante como un tumor osteogénico y clásicamente separado del fibroma cementificante, tenido por odontogénico. ${ }^{4}$

Hoy en día, hay un acuerdo general de que ambos se consideran una única neoplasia osteogénica, con gran variedad expresiva desde el punto de vista histológico: algunos tumores contienen

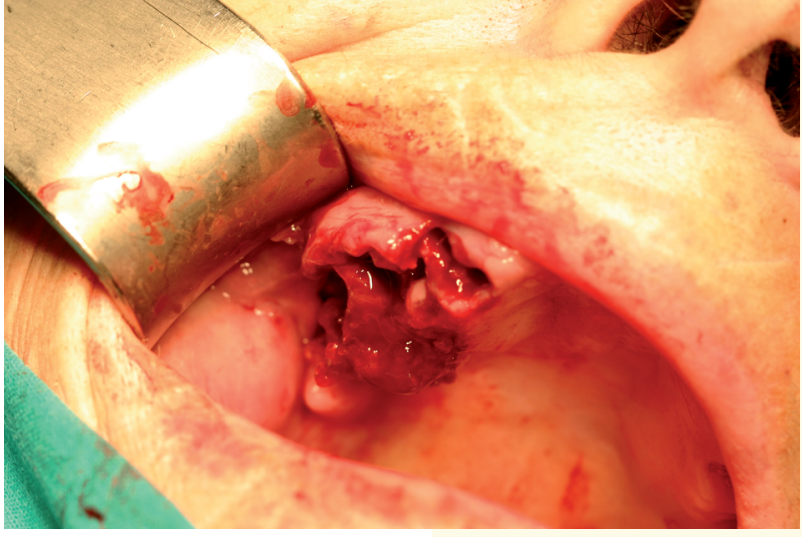

Figura 3. Tratamiento quirúrgico. Figure 3. Surgical treatment.

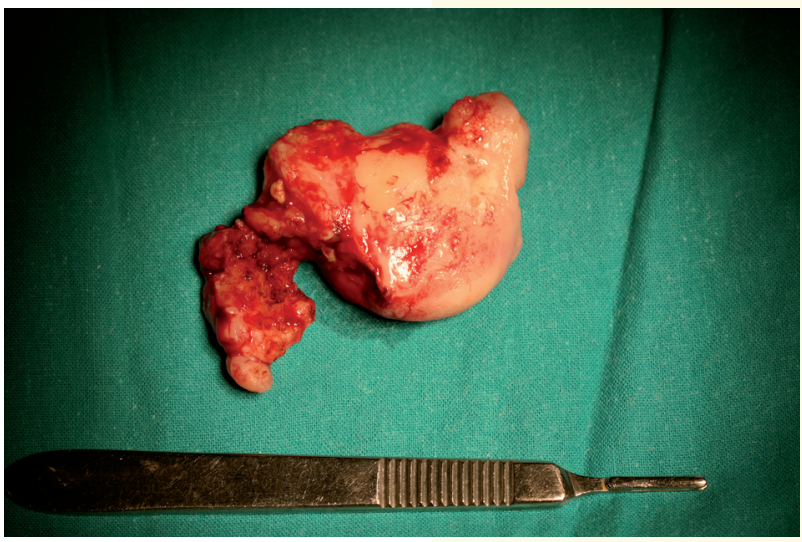

Figura 4. Especimen. Figure 4. Especimen. solamente calcificaciones de aspecto cementario, otros, sólo material óseo, y un tercer grupo, una mezcla de ambas calcificaciones. La separación de estas entidades es extremadamente subjetiva, lo que ha dado lugar a la denominación de fibroma cemento-osificante en la clasificación de la OMS de 1992,2,5,6,8 y englobándolo dentro de los tumores no odontogénicos. ${ }^{3}$ Se acepta para este tumor un origen mesodérmico, siendo una neoplasia fibro-ósea que se origina de células multipotenciales del ligamento periodontal.2,7

El fibroma osificante es una lesión relativamente rara y se presenta con mayor prevalencia en mujeres en la tercera y cuarta década de la vida. Estos tumores pueden ser relacionados con antecedentes de trauma e irritación gingival, exodoncia y periodontitis, ${ }^{2}$ como el caso que nos ocupa, que podría ser inducido por el trauma constante de una prótesis mal ajustada.

El curso evolutivo suele ser muy lento, característica que demuestra la benignidad del proceso. ${ }^{3}$

La presentación del fibroma osificante es fundamentalmente como una neoplasia intraósea, aunque se han descrito casos como el que nos ocupa que afectan a encía y tejidos blandos. ${ }^{7}$ Los de aparición intraósea se describen con predilección por el área molar mandibular, seguido por la localización maxilar, hueso zigomático, classification. ${ }^{2}$ In the past, different terms were used for referring to this lesion: osteofibroma, fibro-osteoma, cementifying fibroma, fibroosseous benign lesion of the periodontal ligament... creating great confusion with regard to terminology. This is due firstly to it being impossible to differentiate them clinically and radiologically, and secondly to the difficulty in distinguishing the origin of the calcified material (bone tissue or cement), the latter being a point of great controversy. ${ }^{6}$ Therefore, the ossifying fibroma was considered an osteogenic tumor and it was classified separately from the cementifying fibroma that was thought to be odontogenic. ${ }^{4}$

There is currently general agreement as to their both being just one osteogenic neoplasm, with great expressive variety from the histological point of view: some tumors only contain calcifications with a cement-like appearance, others only bony material, and a third group has a mixture of both calcifications. The separation of these entities is extremely subjective, and this has led to it being referred to as a cemento-ossifying fibroma by the WHO in 19922,5,6,8 within nonodontogenic tumors. ${ }^{3}$ This tumor's mesodermic origin has been accepted, and it is a fibro-osseous neoplasm originating in multipotential cells of the periodontal ligament.2,7

The ossifying fibroma is a relatively rare lesion and there is a greater prevalence in women in the third and fourth decades in life. These tumors can be related to a history of trauma and irritation of the gingiva, exodontia and periodontitis, ${ }^{2}$ as in this case of ours, which could have been induced by constant trauma from a mal-adjusted prosthesis.

It evolves very slowly, a characteristic indicating that the process is benign. ${ }^{3}$

The ossifying fibroma presents mainly as an intraosseous neoplasm, although cases have been described, such as the one we are dealing with, that affect the gingiva and soft tissues. ${ }^{7}$ Those that are intraosseous are described as having a predilection for the mandibular molar area, followed by 
etmoides, hueso frontal y región petromastoidea.2,5 Nuestro caso se evidenció en maxilar superior al igual que otros fibromas osificantes periféricos. ${ }^{7}$

En cuanto al diagnóstico diferencial fundamentalmente de las presentaciones intraóseas debemos incluir la displasia fibrosa, el osteoma osteoide, el osteoblastoma, el osteosarcoma de bajo grado, el cementoblastoma, la displasia cemento-ósea periapical y focal, el fibroma cemento-osificante juvenil, osteomielitis crónica y la osteomielitis esclerosante de Garré. 3,7

Suele ser asintomático en sus fases iniciales y es bastante frecuente diagnosticarlo en estadios avanzados, como un aumento de volumen localizado, indoloro y que suele ocasionar una importante deformidad estética y funcional. 3,4 Es el caso de nuestra paciente, que debido al gran tamaño de la lesión ocupa todo la bóveda palatina imposibilitando maniobras de intubación.

Como ya hemos comentado, histológicamente se describe esta lesión como un estroma de tejido fibroso con variabilidad celular y calcificaciones que consisten en masas redondeadas (cementumlike), trabeculas osteoides o una combinación de ambas. ${ }^{3}$ En el caso que nos ocupa predominan las trabéculas óseas.

Radiológicamente suele describirse como una lesión bien delimitada con áreas de calcificación, rodeada de un margen esclerótico, cuando se trata de un fibroma cemento-osificante de presentación intraósea. Puede aparecer como una lesión radiolúcida, radiopaca, o mixta, dependiendo de la cantidad de tejido mineralizado que tenga en su interior. Suele ser una lesión unilocular bien delimitada que puede asociarse a reabsorción radicular u ocasionar el desplazamiento de raíces vecinas. ${ }^{1}$

El tratamiento es quirúrgico, consistente en la enucleación del tumor y el legrado de su lecho óseo. Suele tratarse de un tumor bien delimitado, rodeado por una cápsula fibrosa relativamente hipovascular ${ }^{3}$ hecho que facilita la exéresis, como el caso que nos ocupa, y que permite diferenciar la presentación intraósea de la displasia fibrosa. ${ }^{4}$

Presenta un buen pronóstico y la recurrencia es rara cuando el tratamiento es el adecuado con enucleación y curetajes del lecho óseo. $2,4,8$ No se ha encontrado ningún caso de malignización de este tipo de tumor. ${ }^{2,4} \mathrm{El}$ seguimiento clínico debe ser durante varios años, debido al lento crecimiento del tumor, con realización de radiografías panorámicas. ${ }^{6}$

\section{Conclusiones}

La clínica y las características histológicas del caso descrito nos conducen al diagnóstico final de fibroma cemento-osificante periférico de encía superior. Aunque la lesión fue enucleada por completo, la paciente debe ser controlada mediante seguimientos clínicos y radiológicos anuales.

\section{Bibliografía}

1. Regezzi JA, Sciuba J. Oral Pathology: clinical-pathologic correlations. 2nd ed. Philadelphia: WB Saunders 1993;383-6. the maxillary area, zygomatic bone, ethmoid, frontal bone and petromastoid region., 2,5 Our case appeared in the upper maxilla, as have other peripheral ossifying fibromas. ${ }^{7}$

With regard to the differential diagnosis, which concerns fundamentally intraosseous lesions, we should include fibrous dysplasia, osteoid osteoma, osteoblastoma, low-grade osteosarcoma, cementoblastoma, periapical and focal cemento-osseous dysplasia, juvenile cemento-ossifying fibroma, chronic osteomyelitis and Garré's sclerosing osteomyelitis. 3,7

It tends to be asymptomatic in the initial phases, and it is frequently diagnosed in advanced stages, as a localized volume increase that is painless, and which usually leads to considerable aesthetic and functional deformity. ${ }^{3,4}$ With regard to our patient, given the large size of the lesion, which was taking up the entire palatal vault, intubation maneuvers were impossible.

As previously mentioned, histologically this lesion is described as a stroma of fibrous tissue with cellular variability and calcifications that consist in rounded (cementum-like) masses, osteoid trabeculae or a combination of both. ${ }^{3}$ In this case of ours, bone trabeculae predominated.

Radiologically, when the cemento-ossifying fibroma is intraosseous, it tends to be described as a well-defined lesion with areas of calcification and a sclerotic margin. It may appear as radiolucid, radiopaque or mixed, depending on the quantity of mineralized tissue in its interior. It tends to be a unilocular lesion that is well-defined and that can be related to root resorption, or it can cause neighboring roots to shift. ${ }^{1}$

Treatment is surgical, and it consists in the enucleation of the tumor and curettage of the bony bed. It tends to be a well-defined lesion, surrounded by a fibrous, relatively hypovascular capsule, 3 which facilitates exeresis, as occurred in this case of ours. This permits differentiating between intraosseous lesions and fibrous dysplasia. ${ }^{4}$

Prognosis is good and recurrence is rare when adequate treatment including enucleation and curettage of the bony bed is carried out. ${ }^{2,4,8}$ Cases of malignant transformation of this type of tumor have not been reported.2,4 The clinical follow-up should be over various years due to the slow growth of the tumor and panoramic radiographs should be carried out. ${ }^{6}$

\section{Conclusion}

The clinical and histological characteristics of the case described led us to the final diagnosis of peripheral cemento-ossifying fibroma of the upper gingiva. Although the lesion was enucleated completely, the patient should be followed yearly clinically and radiologically. 
2. Martín-Granizo R, de Pedro Marina M. Lesión mixta radiolúcida-radiopaca mandibular en paciente con ameloblastoma previo. Casos clínicos. SECOM on line.

3. Galdeano M, Crespo Pinilla JI, Álvarez Otero R, Espeso A, Terrier A. Fibroma cemento-osificante gingival mandibular: presentación de un caso. Med Oral Patol Oral Cir Bucal 2004;9:176-9.

4. De Vicente Rodríguez JC, González Méndez S, Santamaría Zuazua J, Rubiales B. Tumores no odontogénicos de los maxilares: clasificación, clínica y diagnóstico. Med Oral 1997;2:83-93.
5. Waldrom CA. Fibro-osseus lesions of the jaws. J Oral Maxillofacial Surgery 1993;51:828-35.

6. Marx RE, Stern D. Benign neoplasm of the bone. En: Oral and Maxillofacial pathology. ed Quintessence 2003;(17):789-96.

7. Martín Granizo R, Sánchez- Cuellar LA, Falahat F. Cemento-ossifying fibroma of the upper gingivae. Otolaryngol Head Neck Surg 2000; 122:755.

8. Ertug E, Meral G, Saysel M. Cemento-ossifying fibroma: a case report. Oral Pathol 2004;35:808-10. 